\title{
PELATIHAN MEMBUAT KELAS DAN SOAL MATEMATIKA DI GOOGLE CLASS ROOM DI MTS SWASTA YPI SUBULULHUDA DESA SAENTIS
}

\author{
Rusmini*, Doni Irawan Saragih \\ Universitas Potensi Utama \\ *rusminiponsan@yahoo.co.id
}

\begin{abstract}
Education and training is one of the fundamental things in human life, this training aims to provide information on how to create classes and create questions on the Google form in the Google Classroom application. This activity was carried out for 1 day face to face by following the health protocol where the activity was only attended by 10 people. This training was conducted at YPI Subululhuda, Saentis Village. After the training and mentoring show that the participants had a better motivation and level of knowledge than before, the activity regarding making classes and math problems on the Google form in the Google classroom application. For the continuation program by evaluating the activities of teachers at YPI Subululhuda Saentis Village online using Zoom or Whats app media.
\end{abstract}

Keywords: Training, Creating a Class, Math Problems, Google Classroom

\begin{abstract}
Abstrak
Pendidikan dan pelatihan merupakan salah satu hal yang pundamental dalam kehidupan manusia, Pelatihan ini bertujuan untuk memberikan informasi tentang bagaimana cara membuat kelas dan membuat soal pada google form di aplikasi google classroom. Kegiatan ini dilakukan selama 1 hari secara tatap muka dengan mengikuti protokol kesehatan yang mana kegiatan hanya diikuti oleh 10 orang. Pelatihan ini dilakukan di MTs Swasta YPI Subululhuda Desa Saentis. Setelah dilakukan pelatihan dan pendampingan menunjukkan bahwa peserta memiliki motivasi dan tingkat pengetahuan lebih baik dibanding sebelum kegiatan mengenai membuat kelas dan soal matematika pada Google form di aplikasi google classroom. Untuk program kelanjutannya dengan mengevaluasi kegiatan guru-guru di MTs Swasta YPI Subululhuda Desa saentis secara daring dengan menggunakan media Zoom atau Whatsapp.
\end{abstract}

Kata Kunci: Pelatihan,Membuat Kelas,Soal Matematika,Google Clssroom

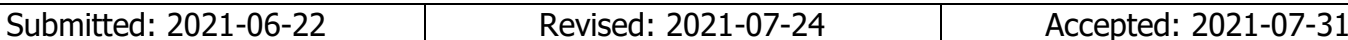

\section{Pendahuluan}

Pendidikan adalah aspek yang sangat berharga untuk meningkatkan sumber daya manusia. Pendidikan juga merupakan suatu yang fundamental dalam kehidupan manusia (Maharani, 2021). Oleh karena itu aspek pendidikan harus mengalami perkembangan yang sangat pesat seiring dengan kemajuan teknologi. Perkembangan teknologi telah membawa paradigma pembelajaran yang berbasis kelas menjadi online (Surahmat \& Fahmi Ajismanto, 2021), hal ini merupakan salah satu cara alternative pembelajaran di masa pandemic. Pembelajaran online juga merupakan cara untuk meningkatkan pendidikan dengan menata cara mendidik peserta didik. Selain itu juga dengan membuat kegiatan belajar dan mengajar menjadi menarik juga meningkatkan ketrampilan guru baik dalam menyajikan materi maupun dalam membuat soal-soal matematika berbasis kelas online.

Seiring dengan kemajuan teknologi yang begitu pesat dan menyikapi kondisi yang lagi dihadapi maka Lembaga Penelitian dan Pengabdian Masyarakat Universitas Potensi Utama bertanggung jawab mengembangkan dan menyebarkan ilmu pengetahuan dan teknologi yaitu dengan mengadakan workshop pelatihan membuat kelas dan membuat soal-soal matematika di Google Classroom untuk meningkatkan kemampuan guru dalam menyajikan materi dan membuat soal-soal matematika pada saat pembelajaran daring (online) di MTs Swasta YPI Subululhuda Desa Saentis. Dengan adanya pelatihan ini guru-guru MTs Swasta YPI Subuluhuda Desa Saentis sudah mempersiapkan diri dalam menghadapi kondisi di kelas yang tidak bisa sepenuhnya diadakan pembelajaran tatap muka secara normal sehingga solusi untuk sementara yaitu mengadakan proses pembelajaran secara daring dengan menggunakan aplikasi Google Classroom agar proses 
pembelajaran tetap berjalan baik dalam memberikan materi maupun membuat evaluasi. Hal ini merupakan suatu upaya dalam menghadapi masa pandemic. Hal senada dengan kegiatan pengabdian masyarakat yang dilakukan oleh (Ariyanto et al., 2020), juga senada dengan kegiatan pengabdian masyarakat yang dilakukan oleh (Sukamta et al., 2020) yang mana pembelajaran berbasis Learning Managemen System jauh lebih menyenangkan dan lebih efektif di masa Pandemic.

Adapun sekilas tentang Google Classroom adalah sebagai berikut: Google Classroom (Ruang Kelas Google) adalah suatu serambi aplikasi pembelajaran campuran secara online yang dapat digunakan secara gratis. Pendidik bisa membuat kelas mereka sendiri dan membagikan kode kelas tersebut atau mengundang para siswanya. Google Classroom ini diperuntukkan untuk membantu semua ruang lingkup pendidikan yang membantu siswa untuk menemukan atau mengatasi kesulitan pembelajaran, membagikan pelajaran dan membuat tugas tanpa harus hadir ke kelas. Google Classroom juga dapat memberikan umpan balik kepada siswa secara efisien dan berkomunikasi bersama siswa tanpa terbatas oleh ruang dan waktu (El Fauziah et al., 2019)

Tujuan utama Google Classroom adalah untuk merampingkan proses berbagi file antara guru dan siswa Google Classroom menggabungkan Google Drive untuk pembuatan dan distribusi penugasan, Google Docs, Sheets, Slides untuk penulisan, Gmail untuk komunikasi, dan Google Calendar untuk penjadwalan. Siswa dapat diundang untuk bergabung dengan kelas melalui kode pribadi, atau secara otomatis diimpor dari domain sekolah. Intinya Google Classroom secara umum mempunyai manfaat diantaranya 1) pembelajaran bisa dilakukan secara daring, 2) fleksibel dan tidak terbatas oleh ruang dan waktu, 3) materi mudah diakses oleh siswa, 4) meningkatkan ketrampilan literasi data dan literasi teknologi (Rahmanto \& Bunyamin, 2020)

Setiap kelas membuat folder terpisah di Drive masing-masing pengguna, dimana siswa dapat mengirimkan pekerjaan untuk dinilai oleh guru. Aplikasi ini tersedia bagi pengguna seluler perangkat iOS dan Android yang memungkinkan pengguna mengambil foto dan melampirkan penugasan, berbagi file dari aplikasi lain dan mengakses informasi secara offline. Guru dapat memantau kemajuan untuk setiap siswa, dan setelah dinilai, guru dapat kembali bekerja bersama dengan komentar.

Pelatihan membuat soal matematika dengan media Google Classroom untuk meningkatkan ketrampilan guru dalam pembelajaran berbasis ICT. Workshop ini diharapkan mampu memberikan pengetahuan kepada guru untuk memanfaatkan pembelajaran dengan media Google Classroom untuk meningkatkan ketrampilan guru dalam merancang pembelajaran berbasis ICT. Pelatihan membuat soal matematika dengan media Google Classroom ini akan diadakan selama 1 hari. Kegiatan ini meliputi pengenalan terhadap media Google Classroom, membuat soal matematika dengan Google form dan membuat lembar angket. Selanjutnya membagikan software langkah-langkah membuat Google Class online.

Semoga dengan adanya worskhop pembelajaran dengan media Google Classroom bisa meningkatkan kemampuan dan ketrampilan guru dalam membuat soal dan mendapat wawasan serta informasi tentang bagaimana memanfaatkan media pembelajaran Google Classroom pada masa pandemic dengan lebih baik. Berdasarkan informasi yang ada bahwa pembelajaran dengan aplikasi Google Classroom di masa pandemic sangat efisien dan efektif serta meningkatkan motivasi dan kreatifitas baik bagi guru maupun siswa, hal ini senada dengan penelitian (Kelana \& Wardani, 2021).

\section{Metode:}

Metode kegiatan pengabdian dilakukan dengan pelatihan dan pendampingan. Kegiatan tersebut dilaksanakan dengan dua tahap, yaitu tahap persiapan dan tahap pelaksanaan. Berikut dijelaskan masingmasing tahap kegiatan : 
1. Tahap Persiapan

Tahap ini meliputi kegiatan perizinan ke pihak pengurus sekolah MTs Swasta YPI Subululhuda Desa Saentis. Dalam tahap ini dilakukan juga koordinasi antara tim dan khalayak sasaran, mempersiapkan materi kegiatan seperti materi prresentasi dan materi pelatihan, kuisoner, dan alat evaluasi lain.

2. Tahap Pelaksanaan

Tahap ini dibagi dalam dua bagian yakni pelaksanaan pelatihan dan pendampingan. Tahap pelaksanaan pelatihan meliputi kegiatan presentasi materi, simulasi, pengolahan data, diskusi dan Tanya jawab antara tim dengan khalayak, dan evaluasi akhir menggunakan pengolahan data dan kuisoner. Bagian pertama dilaksanakan dengan satu kali pertemuan yaitu pada tanggal 11 November 2020. Untuk bagian pendampingan analisis data dilaksankan selama 3 bulan yaitu mulai bulan Desember sampai dengan Januari 2021.

Tim pelaksanaan kegiatan pengabdiaan kepada masyarakat ini terdiri dari 2 orang dosen jurusan Matematika. Subjek kegiatan ini adalah guru-guru MTs Swasta YPI Subululhuda sebanyak 10 orang. Materi dalam pelatihan ini meliputi : a) Membuaat kelas di Google Classroom, b) Membuat soal matematika dalam bentuk soal assay di Google form, 3) Assesment di Google Classroom. Kegiatan pelatihan ini dilakukan di YPI S Subululhuda Desa Saentis Jl. Musyawarah F Kec. Percut Sei Tuan Kab. Deli Serdang.

3. Tahap Akhir

Pada tahap akhir membuat evaluasi dalam bentuk quisoner dengan memberikan angket kepada peserta dan menganalisis data dan memaparkannya secara deskripsi dengan tabel dan diagram. Selanjutnya menyimpulkan hasil kegiatan dan mempublikasikan di jurnal Pengabdiam Kepada Masyarakat

\section{Hasil dan Pembahasan}

Hasil dari setiap program pelatihan yang telah dilaksanakan dijelaskan sebgai berikut :

A. Pelatihan membuat kelas di Google Classroom

Pelatihan ini bertujuan untuk mengajarkan peserta pelatihan (guru) bagaimana cara membuat kelas di Google Classroom dalam pelaksanaan pembelajaran daring, selain itu juga diperkenalkan membuat soal assy dan assessment di Google Classroom. Topik yang diajarkan bagaimana cara membuat kelas, mengunggah bahan ajar, membuat soal dan melakukan assesmen atau penilaian tugas siswa secara daring di Classroom. Pelaksanaan kegiatan yang dilakukan pada tanggal 11 November 2020 dapat dilihat pada Gambar 1 di bawa
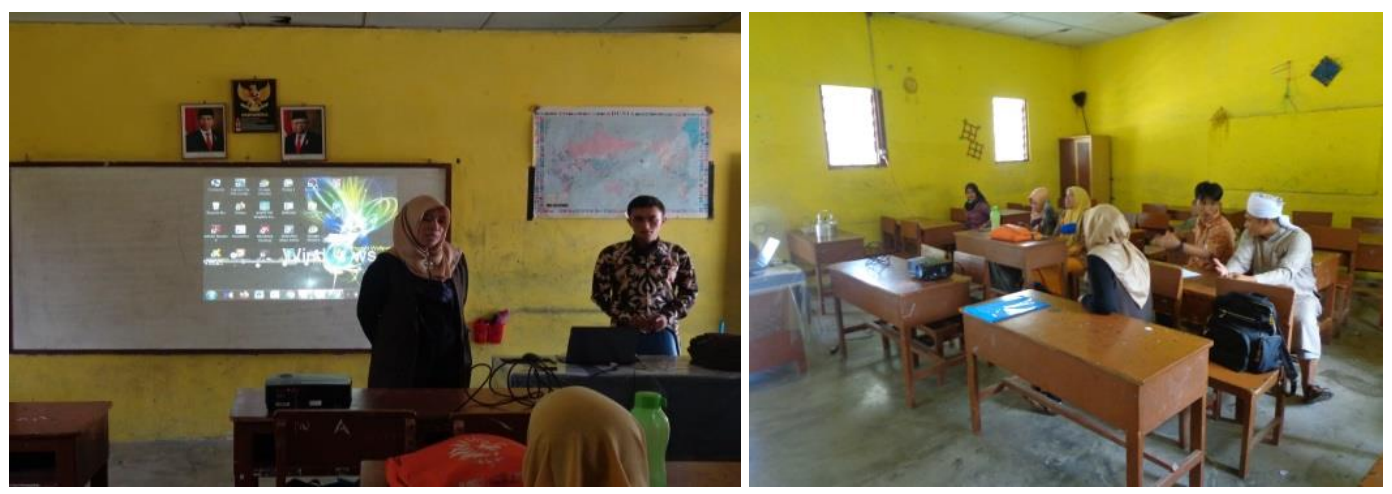

Gambar 1. Pelatihan Membuat Kelas di Google Classroom 
B. Pelatihan membuat Soal Assay

Pelatihan membuat soal Assay dilakukan di hari itu juga yaitu pada sesi ke 2 dengan memperkenalkan langkah-langkah membuatnya. Adapun icon kelas dan icon membuat soal ditunjukkan pada Gambar 2.

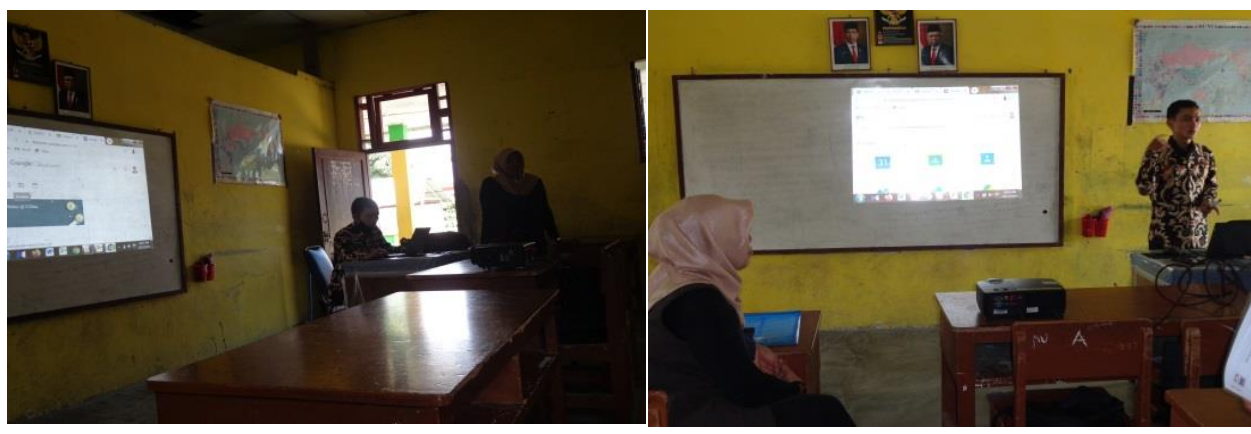

Gambar 2. Pelatihan Membuat

C. Diskusi Tentang kendala yang dihadapi pada pelatihan

Setelah dilakukan pengarahan tentang langkah-langkah membuat kelas di Google Classroom dan membuat soal Assay maka pada sesi setelah istirahat makan siang dilakukan acara diskusi untuk mengutarakan kendala yang dihadapi oleh peserta pelatihan dan dilakukan photo bersama sesama peserta dan tim pelatihan. Adapun dokumentasi acara diskusi bisa dilihat pada Gambar 3.
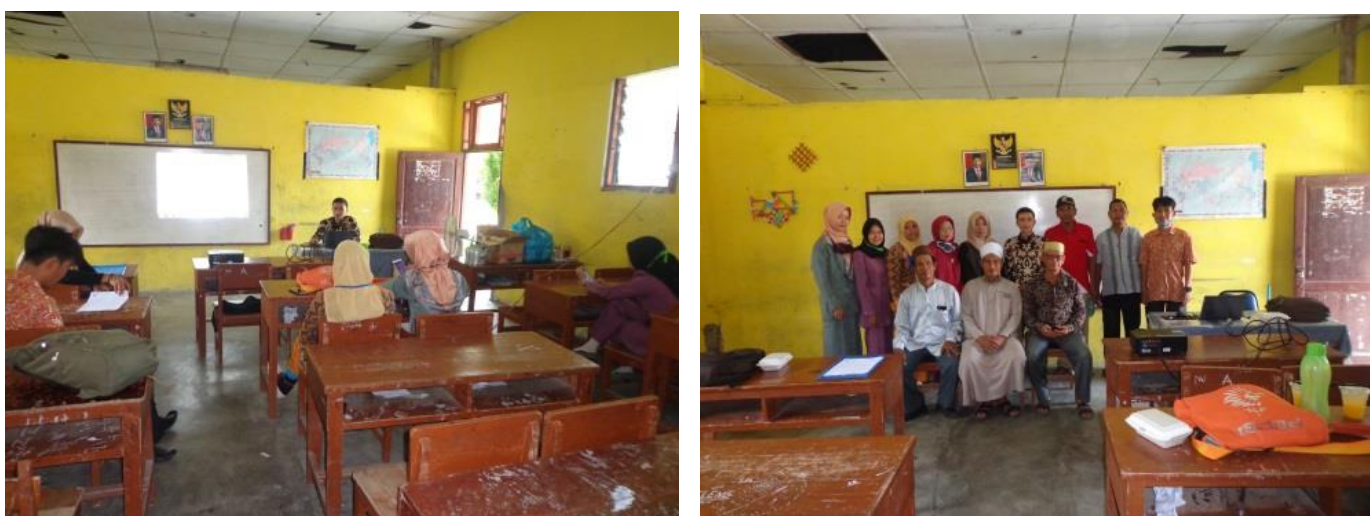

Gambar 3. Diskusi Tentang Kendala Yang dihadapi Pada Pelatihan

Berdasarkan hasil diskusi maka dapat disimpulkan bahwa para guru menginginkan pendampingan secara berkelanjutan yang bisa dilakukan secara daring via zoom atau melalui Whats app. Alasannya guru sering lupa mengakses laman atau membuat point-point langkahlangkah membuat soal Assay di Google Form

\section{Dampak pelatihan Membuat Kelas dan Soal matematika di Google Classroom.}

Keberhasilan dari kegiatan pelatihan ini tentunya dapat diukur berdasarkan indicator pengetahuan dan peningkatan ketrampilan peserta pelatihan sebagaimana ditunjukkan pada Tabel 1 di bawah ini, 
Tabel 1. Indikator Pencapaian Peserta Kegiatan Pelatihan

\begin{tabular}{cccc}
\hline No & Program Pelatihan & Jumlah Peserta & Hasil \\
\hline 1 & $\begin{array}{c}\text { Membuat Kelas di } \\
\text { Google Classroom }\end{array}$ & 10 & $\begin{array}{c}\text { Dari 10 orang 4 orang } \\
\text { kategori baik sekali , 3 } \\
\text { orang baik dan 3 } \\
\text { orang kategori cukup } \\
\text { Dari 10 orang hany 3 } \\
\text { orang kategori baik } \\
\text { dan 7 orang kategori } \\
\text { cukup }\end{array}$ \\
& $\begin{array}{c}\text { Membuat Soal Assay } \\
\text { di Google Form }\end{array}$ & 10 & $\begin{array}{c}\text { Dari 10 orang } 7 \text { orang } \\
\text { kategori sangat baik } \\
\text { dan 3 orang kategori } \\
\text { baik. }\end{array}$ \\
\hline
\end{tabular}

Berdasarkan Tabel 1 indikator pencapaian peserta kegiatan pelatihan dapat dilihat bahwa pada umumnya hasil menunjukkan pencapaian peserta kegiatan pelatihan membuat kelas, membuat soal di Google Classroom, memberi penilaian hasil kerja siswa dengan kategori baik. Adapun apabila hasil kegitan ditunjukkan dengan diagram batang maka dapat dilihat sebagai berikut,

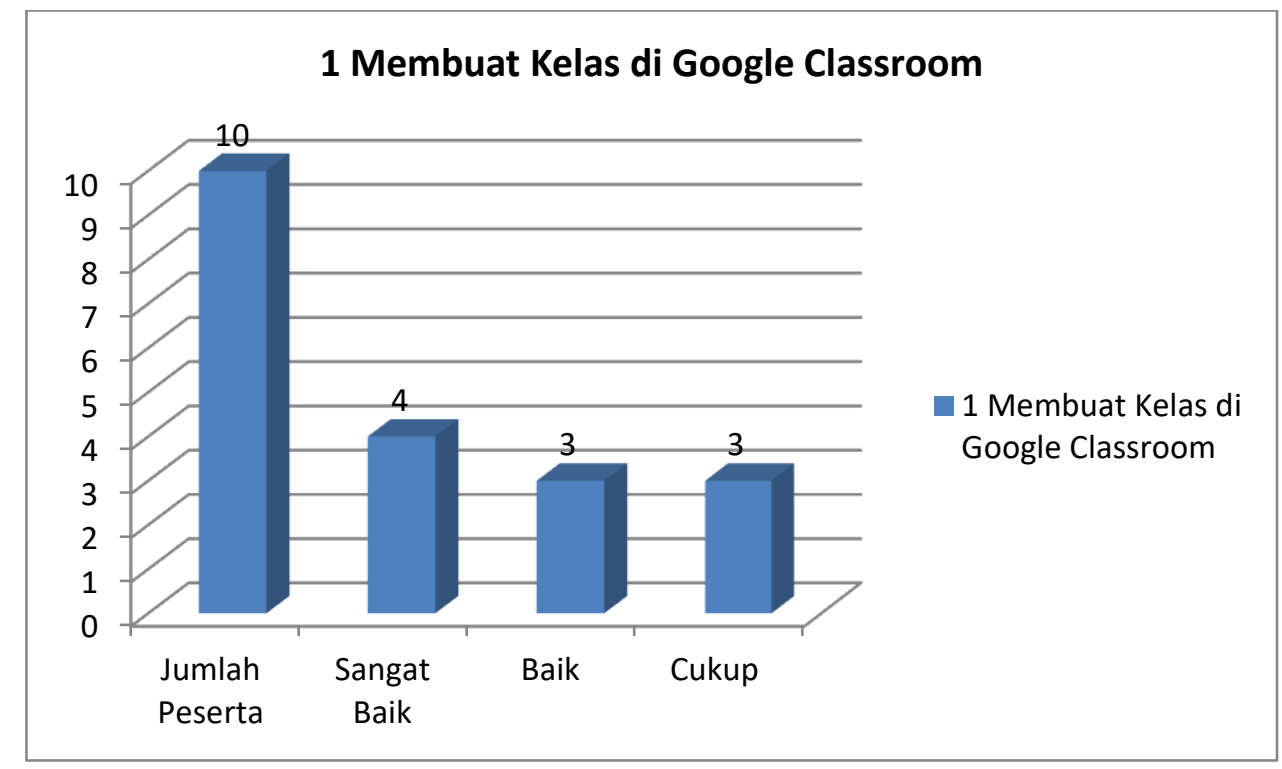

Gambar 4. Grafik Membuat Kelas di Google Classroom

Berdasarkan Gambar 4 grafik membuat kelas di Google Classroom dapat dilihat bahwa dari 10 orang peserta pelatihan yang mendapat kriteria sangat baik sebanyak 4 orang guru hal ini mungkin guru ini sudah pernah belajar atau bahkan sudah menggunakan aplikasi google classroom sebelum pelatihan ini, selanjutnya dengan kriteria baik sebanyak 3 orang guru berdasarkan wawancara dengan guru tersebut mereka pernah mendengar aplikasi Google Classroom namun belum menginstal atau menggunakan aplikasi tersebut dalam pembelajaran. Sementara untuk 3 orang guru dengan kriteria cukup hal ini disebabkan mereka jarang menggunakan android sebagai alat komunikasi sehari-hari sehingga pada saat diperkenalkan dengan aplikasi tersebut mereka masih belajar menggunakan dari awal langkah-langkah menginstal aplikasi dan menggunakan aplikasi tersebut dalam membuat kelas sebagai media pembelajaran. Selanjutnay untuk indicator pencapaian ketrampilan membuat soal assay di Google Classroom yang disajikan dalam diagram batang dapat dilihat pada Gambar 5 sebagai berikut, 


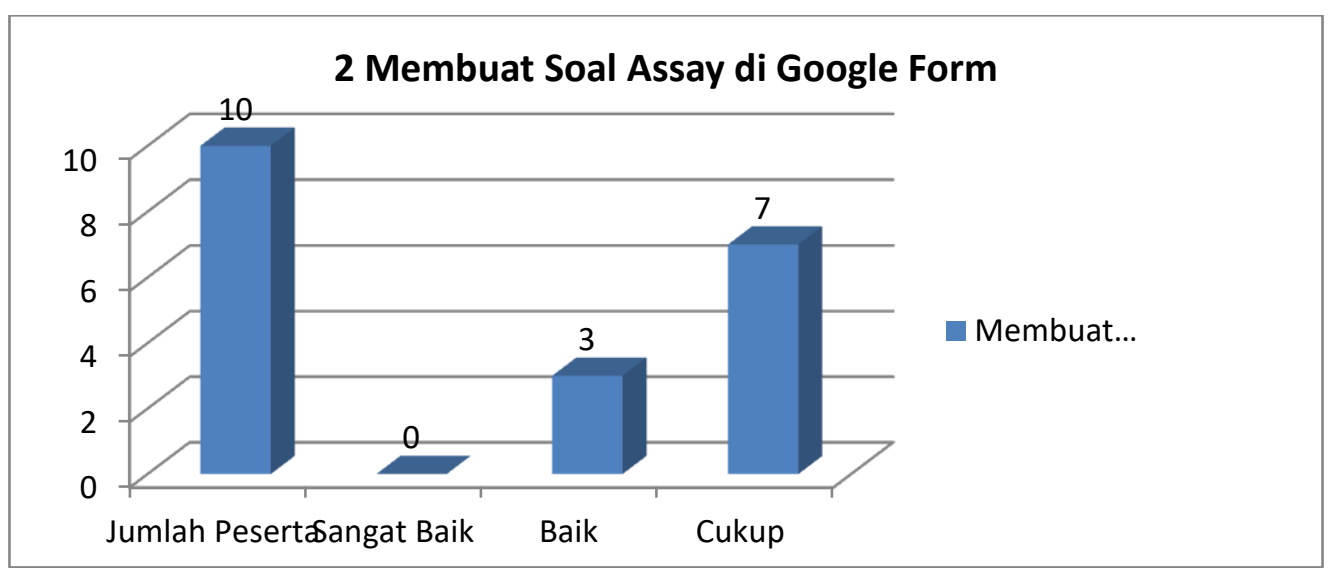

Gambar 5. Membuat Soal Assay di Google Form

Berdasarkan Gambar 5 Membuat soal Assay di Google Form dapat dilihat bahwa dari 10 orang guru yang mengikuti pelatihan untuk krireria sangat baik tidak ada atau sebanyak 0 , menurut mereka agak susah membuatnya apalagi kalau soal tersebut jenis soal assay mata pelajaran matematika yang menggunakan symbol dan rumus-rumus matematika dan untuk kriteria baik ada sebanyak 3 orang (30\%) menurut mereka memang agak susah namun bila sering dilakukan maka hal yang susah dan rumit agak menjadi mudah, selanjutnya untuk kriteria cukup ada sebanyak 7 orang $(70 \%)$, yang mana kita dari tim memang harus mendampingi hingga mereka paham. Diagram batang untuk indicator ketrampilan memberi penilaian hasil kerja dapat dilihat pada Gambar 6 sebagai berikut,

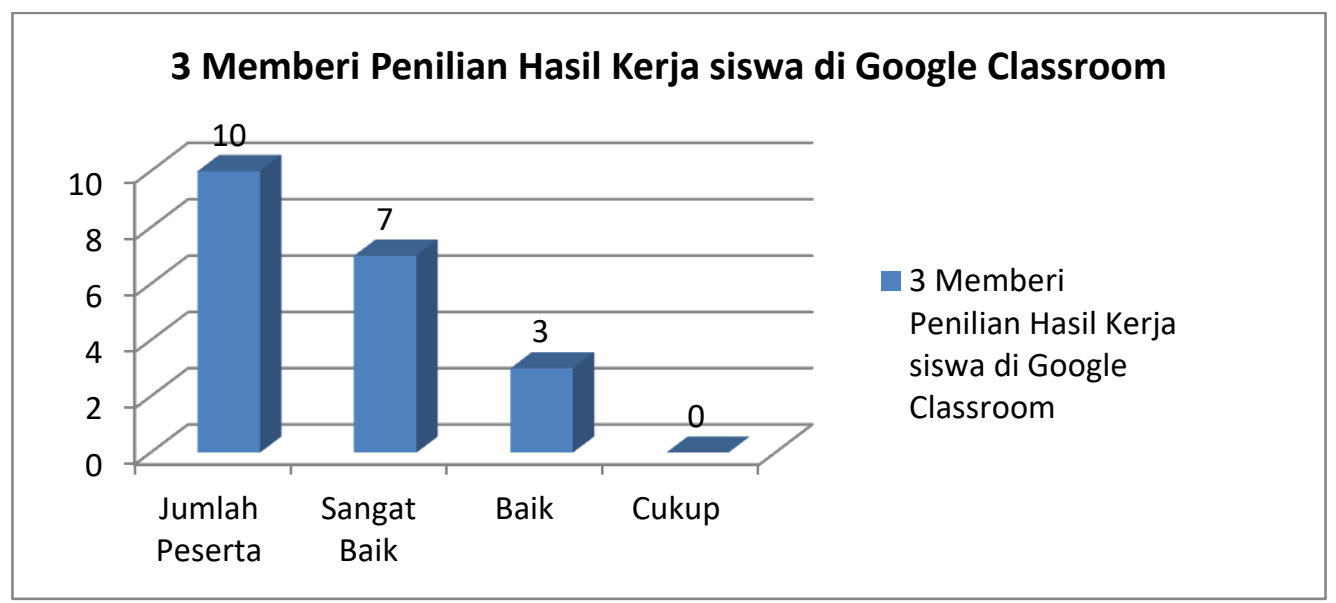

Gambar 6. Memberi Penilaian Hasil Kerja Siswa di Google Classroom

Berdasarkan Gambar 6 memberi penilaian hasil kerja siswa di Google Classroom maka dapat dilihat bahwa untuk kriteria Sangat baik sebanyak 7 orang artinya lebih dari $50 \%$ dan untuk kriteria baik sebanyak 3 orang (30\%). Berdsarkan hasil dari ketiga indicator kemampuan membuat kelas, membuat soal dan memberi penilaian secara umum setelah pelatihan ketrampilan guru-guru menjadi lebih baik dalam hal pengelolaan kelas dengan media online seperti Google Classroom. Hal ini senada dengan penelitian (Hamdani et al., 2020) juga senada dengan peneltian (Fatira et al., 2020) dan penelitian (M., 2018)

\section{Kesimpulan}

Berdasarkan pembahasan dapat disimpulkan bahwa pelatihan membuat kelas dan soal matematika di Google Classroom kepada guru di Mts YPI Swasta Subululhuda Desa Saentis memberikan manfaat yang luar biasa untuk para guru. Guru sangat antusias dan tertarik dengan penggunaan Google Classroom. Dengan adanya aplikasi tersebut mereka bisa menggunakan 
dalam pembelajaran, guru dapat lebih mudah untuk mengelola kelas, lebih hemat waktu dan memberikan contoh kepada siswa untuk menjaga lingkungan dengan menghemat penggunaan kertas. Namun yang menjadi kendala bagi guru adalah biaya untuk menfasilitasi penggunaan koneksi internet yang sering menjadi masalah karena biaya untuk membeli pulsa atau paket data bagi siswa menjadi beban begitu juga bagi guru-guru. Hal ini juga menjadi perhatian bagi institusi untuk memberikan fasilitas yang memadai agar pelatihan dan pelaksanaan pembelajaran secara berkelanjutan bisa terlaksana dengan baik dan berkelanjutan. Sehingga sinergi yang baik dibutuhkan tidak hanya kreatifitas guru saja yang dituntut oleh institusi kepada guru dalam meningkatkan tercapainya kualitas pembelajaran yang lebih baik lagi.

\section{Daftar Pustaka}

Ariyanto, S. R., Ardiyanta, A. S., Soeryanto, S., Warju, W., Hidayatullah, R. S., \& Dianastiti, Y. (2020). Pelatihan Pembelajaran Daring Sebagai Langkah Persiapan Guru Smk Dalam Melaksanakan Learning From Home Di Masa Pandemi Covid-19. Jurnal Pemberdayaan: Publikasi Hasil Pengabdian Kepada Masyarakat, 4(3), 311. https://doi.org/10.12928/jp.v4i3.2263

El Fauziah, U. N., Suryani, L., \& Syahrizal, T. (2019). Penerapan Google Classroom Dalam Pembelajaran Bahasa Inggris Kepada Guru-Guru Bahasa Inggris Smp Di Subang. Abdimas Siliwangi, 2(2), 183. https://doi.org/10.22460/as.v2i2p183-191.3281

Fatira, M., Syafitri, E., Ramadhani, R., \& Mesran. (2020). Peningkatan Kemampuan Guru Dalam Pembelajaran Daring Menggunakan Google Classroom. Mitra Akademia: Jurnal Pengabdian Masyarakat, 3(2), 61-68.

Hamdani, A. U., Suryadi, L., Harsanto, K., \& Broto, S. (2020). Pelatihan Penggunaan Google Class Room Untuk Menunjang Kegiatan Belajar Bagi Guru Smk Muhammadiyah 9 Jakarta. 3(1), 95100.

Kelana, J. B., \& Wardani, D. S. (2021). Pelatihan Peningkatan Pembelajaran Online Di Masa Pandemi Covid-19 Pada Guru Sekolah Dasar. BERNAS: Jurnal Pengabdian ..., 2(2), 426-431. https://doi.org/10.31949/jb.v2i2.943

M., M. (2018). Pelatihan Google Classroom Untuk Mengoptimalisasi Proses Pembelajaran Di Fkip Universitas Tamansiswa Palembang. JURNAL CEMERLANG: Pengabdian Pada Masyarakat, 1(1), 58-70. https://doi.org/10.31540/jpm.v1i1.159

Maharani, F. (2021). Pelatihan Dan Pendampingan Penulisan Esai Aplikasi Beasiswa Dan Studi Lanjut Luar Negeri Secara Daring. BERNAS: Jurnal Pengabdian Kepada Masyarakat, 2(2), 464-468.

Rahmanto, M. A., \& Bunyamin. (2020). Efektivitas Media Pembelajaran Daring Melalui Google Classroom. Jurnal Pendidikan Islam, 11(November), 119-135.

Sukamta, S., Arief, U. M., Subiyanto, S., Andrasto, T., Ekarini, F., Firdaus, A. A., \& Rifaldi, A. (2020). Pelatihan Learning Management System Menggunakan Schoology Pada Guru Di Gugus Ki Hajar Dewantara Kabupaten Semarang. Jurnal Pemberdayaan: Publikasi Hasil Pengabdian Kepada Masyarakat, 4(3), 355. https://doi.org/10.12928/jp.v4i3.2849

Surahmat \& Fahmi Ajismanto. (2021). PELATIHAN PENGGUNAAN APLIKASI GOOGLE MEET SEBAGAI PENUNJANG KEGIATAN BELAJAR MENGAJAR BAGI GURU SEKOLAH DASAR NEGERI 170 PALEMBANG. BERNAS: Jurnal Pengabdian Kepada Masyarakat, 2(2), 552-558. 